\title{
Infraspecific morphological and genetic variations of Ficus carica L. from Iran
}

\author{
Mohammad Reza Zolfaghari, \\ Fahimeh Salimpour ${ }^{*}$ \\ Fariba Sharifnia,
}

Maryam Peyvandi,

\section{Sayeh Jafari Marandi}

Department of Biology,

Tehran North Branch,

Islamic Azad University,

Vafadar Blv.,

Shahid Sadoghi St,

Hakimieh, Tehran, Iran
Ficus carica L. (Moraceae) is one of the most important crop plants widely cultivated in different parts of the world. Several wild or cultivated populations of it grow in various regions of Iran. In the current research, we evaluated morphological and molecular SSR methods in order to investigate infraspecific variations in this species and introduce possible phenotypes/genotypes among its populations. For this, 14 populations were selected from different parts of the country. We evaluated 27 qualitative and quantitative morphological traits of both reproductive and vegetative organs. The ANOVA test revealed significant variations for most of the quantitative variables; moreover, qualitative features differed among populations. Significant correlations were found between some morphological characteristics with ecological factors of habitats. According to the UPGMA tree, four morphotypes existed among these populations. CA-joined plot revealed that each group was identified by some morphological variables. In addition, parameters of genetic diversity varied among the studied populations, while the AMOVA test showed significant variations, most of which belonged to the variations within the population. According to the UPGMA tree, MDS and PCoA plots, the studied populations were divided into four distinct genotypes. In addition, the UPGMA tree based on Nei genetic diversity and Structure analyses confirmed these groups. Three groups were monotypic and the fourth was composed of eleven populations. Patterns of population clustering based on the morphological traits were not similar to those of SSR data. Therefore we concluded that environmental factors had strong effects on the population's phenotype and genotypes were not recognized by their phenotypes.

Keywords: F. carica, SSR, morphology, population, genetic variation

\footnotetext{
*Corresponding author. Email: fahimehsalimpour89@gmail.com
} 


\section{INTRODUCTION}

Ficus carica L. is one of the oldest fruit crops in the world. It belongs to Moraceae family that includes 60 genera and more than 2000 species in the forms of trees, shrubs, and herbs. Ficus has over 1000 taxa, which are classified into about 48 sub-genera (Condit, 1955; Storey, 1975).

Among different Ficus taxa, only two species, F. carica and F. sycamorus, were cultivated for their fruit. F. carica (fig) is cross-pollinated and has a diploid $(2 \mathrm{n}=26)$ genome. Two basic types of $F$. carica (the caprifig and edible figs) were found. The caprifig bears both female and male flowers whereas the edible fig bears only female flowers (Darlington, Wylie, 1955).

Chawla et al. (2012) have described edible figs as small trees with spreading branches and greyish on red bark, green leaves $7-9 \mathrm{~cm}$ long and $4-6 \mathrm{~cm}$ wide, lanceolate in shape; the surface is rough on upper and pale green at lower surface, acute, apex oval, cordate base, serrate margin and reticulate venation, alternate, palmately 3-5 lobed. Inflorescence consists of a pear-shaped, hollow, fleshy, receptacle bearing staminate and pistillate flowers on its inner surface. The tiny flowers of the fig are out of sight, clustered inside the green fruits, technically a synconium.

Several secondary metabolites such as triterpenoids, sterols, coumarins, flavonoids, and anthocyanins were extracted from different parts of this plant. Various pharmacological actions of these metabolites have been reported (Chawla et al., 2012). For example, Jeong et al. (2009) reported a strong antibacterial activity of methanolic extract of figs against oral bacteria. Furthermore, low-molecular-weight extracts of F. carica leaves have antifungal and antibacterial activities against several types of microorganisms (Yan et al., 2011). Administration of the ethanolic extract of the leaves remarkably ameliorated both cellular and humoral antibody response in mice (Patil et al., 2010).

Rahnavard (2017) reported that few studies are available on $F$. carica for understanding the genome structure and its infraspecific gene- tic variation. Molecular techniques are useful tools for the investigation of genetic diversity and population structure; however, morphological and biochemical methods can be used for detecting genetic variations.

A high level of genetic polymorphism created by SSR markers make this technique suitable for inferring relatively recent population genetic events. SSR markers can also be used to genetically discriminate between individuals as well as populations (Freeland et al., 2011).

Therefore, in the current research we used morphological and molecular SSR methods on fourteen populations of $F$. carica in order to investigate infraspecific variations in F. carica and find possible phenotypes/genotypes among the studied populations.

\section{MATERIALS AND METHODS}

In this study, 14 cultivated populations of F. carica were harvested from various parts of Iran (Table 1), and were identified according to descriptions provided in valuable references such as Flora of Iran (Azizian, 2001).

\section{Morphological studies}

Morphological variations were carefully investigated for both vegetative and reproductive organs of the collected populations. Morphological characteristics were evaluated under dissecting stereo microscopes. For morphometric analysis, 70 plant specimens from fourteen populations were examined. Voucher specimens were deposited at Herbarium of Islamic Azad University Tehran (IAUNT).

\section{Character measurements}

Evaluations of morphological characteristics were performed on each collected twig. In total, 27 qualitative and qualitative features were measured for each specimen. Each feature was measured three times per each plant sample, and their averages were determined. The studied characteristics were: stem length, leaf basal, marginal and apical shape, leaf blade length, width and length/width ratio, leaf thickness, leaf colour, leaf lob dimension and number, 
Table 1. Localities and features of the studied populations

\begin{tabular}{|c|c|c|c|c|c|c|c|}
\hline $\begin{array}{l}\text { Popula- } \\
\text { tion No. }\end{array}$ & Locality & $\begin{array}{c}\text { Soil } \\
\mathrm{pH}\end{array}$ & $\begin{array}{l}\text { Soil EC } \\
(\mathrm{dS} / \mathrm{m})\end{array}$ & $\begin{array}{c}\text { Altitude } \\
(\mathrm{m})\end{array}$ & $\begin{array}{l}\text { Longi- } \\
\text { tude }\end{array}$ & $\begin{array}{l}\text { Lati- } \\
\text { tude }\end{array}$ & Herbarium No. \\
\hline 1 & Mazandaran province, Savad kooh & 7.96 & 122.66 & 1500 & $53^{\circ} 38^{\prime}$ & $36^{\circ} 62^{\prime}$ & 17429 IAUNT \\
\hline 2 & Fars province, Estahban & 7.96 & 212 & 1600 & $54^{\circ} 10^{\prime}$ & $29^{\circ} 05^{\prime}$ & 17430 IAUNT \\
\hline 3 & Markazi province, Mahallat & 8.67 & 106.33 & 1550 & $50^{\circ} 27^{\prime}$ & $33^{\circ} 55^{\prime}$ & 17431 IAUNT \\
\hline 4 & $\begin{array}{l}\text { Chaharmahal and Bakhtiari, } \\
\text { Shar-e-Kord }\end{array}$ & 7.69 & 143.66 & 1710 & $50^{\circ} 53^{\prime}$ & $32^{\circ} 17^{\prime}$ & 17432 IAUNT \\
\hline 5 & Ilam province, Ilam & 7.9 & 302.66 & 1460 & $46^{\circ} 23^{\prime}$ & $33^{\circ} 38^{\prime}$ & 17433 IAUNT \\
\hline 6 & Kurdistan province, Sanandaj & 7.83 & 150.60 & 1550 & $46^{\circ} 58^{\prime}$ & $35^{\circ} 18^{\prime}$ & 17434 IAUNT \\
\hline 7 & Yazd province, Yazd & 7.94 & 100 & 1440 & $54^{\circ} 21^{\prime}$ & $31^{\circ} 53^{\prime}$ & 17435 IAUNT \\
\hline 8 & Kerman province, Kerman & 8.18 & 143 & 1420 & $57^{\circ} 04^{\prime}$ & $30^{\circ} 16^{\prime}$ & 17436 IAUNT \\
\hline 9 & Zanjan province, Tarom & 8.08 & 847.7 & 1760 & $48^{\circ} 42^{\prime}$ & $36^{\circ} 54^{\prime}$ & 17437 IAUNT \\
\hline 10 & West Azerbaijan province, Khoy & 7.72 & 375.4 & 1810 & $44^{\circ} 57^{\prime}$ & $38^{\circ} 32^{\prime}$ & 17438 IAUNT \\
\hline 11 & East Azerbaijan province, Aras & 7.75 & 401.5 & 1690 & $45^{\circ} 16^{\prime}$ & $39^{\circ} 60^{\prime}$ & 17439 IAUNT \\
\hline 12 & $\begin{array}{c}\text { Sistan and Baluchistan province, } \\
\text { Chabahar }\end{array}$ & 8.19 & 214 & 20 & $60^{\circ} 64^{\prime}$ & $25^{\circ} 29^{\prime}$ & 17440 IAUNT \\
\hline 13 & Khorasan Razavi, Mashhad & 8.03 & 280 & 1320 & $59^{\circ} 36^{\prime}$ & $36^{\circ} 18^{\prime}$ & 17441 IAUNT \\
\hline 14 & Semnan province, Semnan & 7.97 & 309 & 1390 & $53^{\circ} 23^{\prime}$ & $35^{\circ} 34^{\prime}$ & 17442 IAUNT \\
\hline
\end{tabular}

angle between leaf lops, leaf trichome shape and density on dorsal and ventral sides, petiole length, diameter, colour and trichome shape and fruit colour.

\section{Molecular investigations}

We used six microsatellite primers, MFC1, MFC2, MFC3, MFC6, MFC7, and MFC8 for the amplification of random genomic DNA banding patterns (Khadari et al., 2001). The PCR reactions were carried out in a $25 \mu \mathrm{l}$ volume mixture containing: genomic DNA $3 \mu \mathrm{l}$, $0.25 \mathrm{mM}$ dNTPs, $0.5 \mathrm{mM} \mathrm{MgCl}_{2}$, 9 pmol $(9 \mu$ $\mathrm{M} / \mathrm{L}$ ) primers, $0.5 \mathrm{U}$ of Taq DNA Polymerase, and $1 \mu \mathrm{l}$ enzyme buffer. These reactions were performed in Gene Amp PCR System 9700 Thermal Cycler. The amplification program was as follows: an initial denaturing step at $94^{\circ} \mathrm{C}$ for 3 min followed by 39 cycles of $94^{\circ} \mathrm{C}$ for $45 \mathrm{~s}$, $56.5^{\circ} \mathrm{C}$ for $1 \mathrm{~min}$ and $72^{\circ} \mathrm{C}$ for $2 \mathrm{~min}$, and a final extension at $72^{\circ} \mathrm{C}$ for $5 \mathrm{~min}$.

\section{Statistical analyses}

Quantitative morphological characteristics were subjected to one-way analysis of variance (ANOVA) to determine if significant variations exist- ed among populations for each trait measured. Mean as well as standard deviations of variables were calculated. The mentioned analyses were performed using SPSS v. 15. Cluster analysis was based on quantitative and qualitative characteristics using the Unweighted Paired Group Method with Arithmetic Mean (UPGMA), Principal Coordinate Ordination )PCO), Principal Coordinate Analysis (PCA), and Correspondence Analysis )CA-Joined( plots clustering in Multivariate Statistical Package (MVSP) program (Podani, 2000).

We coded the obtained SSR bands as binary traits (absence $=0$, presence $=1$ ) and applied these codes for later genetic difference analyses. We determined different important genetic parameters such as Nei's gene diversity $(\mathrm{H})$, effective allele's numbers, Shannon information index (I), and the percentage of polymorphism (Freeland et al., 2011). We used Nei's genetic distance among the studied populations for the UPGMA tree clustering and NeighborNet networking (Huson, Bryant, 2006; Freeland et al., 2011).

We used GenAlex 6.4 and GenoDive v.2 software packages for analysis of molecular 
variance (AMOVA) test with 1000 permutations, and Nei's Gst analysis, respectively (Meirmans, Tienderen, 2004; Peakall, Smouse, 2006). Furthermore, we calculated the index of genetic differentiation of population Gst and Dest (Hedrick, 2005).

Evaluation of the genetic structure of the population was based on Bayesian model Structure analysis (Pritchard et al., 2000). Falush et al. (2007) stated that data had to be scored as dominant markers for Structure analysis.

The Evanno analysis was conducted on structure results in order to estimate the best number of $\mathrm{K}$ by using delta $\mathrm{K}$ value (Evanno et al., 2005). Simulations were carried out 10 times for each $\mathrm{K}=$ ? value with 10,000 burn-ins and 50,000 MCMC iterations.

\section{RESULTS}

\section{Morphological investigation}

In the current research, morphological variables of both vegetative and reproductive organs were evaluated. The studied morphological characteristics are presented in Table 2. Both qualitative and quantitative traits differed among the populations.

The leaf basal shape varied among these populations. Two basal shapes were found, truncate and cordate. The basal shape of leaves in most of the populations was truncate. Although two apical shapes of leaves were registered among these populations, the frequencies of their occurrence were nearly equal. Most of the populations had yellow-coloured fruits; however, few populations had black-coloured fruit. The leaf and petiole colour differed among the studied populations. The most observed leaf and petiole colour were dark green and light green, respectively. The density of indumentum and the type of its trichomes differed among the studied populations and most of them had bristle-shaped trichomes.

The ANOVA test revealed significant variations $(p \leq 0.01)$ for all of the studied traits, except for the leaf length/ width ratio (Table 3 ).
The longest $(9.33 \mathrm{~cm})$ and the shortest $(3.23 \mathrm{~cm})$ petioles were registered in populations 1 and 7, respectively. The broadest petiole $(0.27 \mathrm{~cm})$ was observed in population 5 and the narrowest $(0.13 \mathrm{~cm})$ petiole belonged to population 7. Populations 13 and 3 had the largest and the smallest leaf length, respectively. Moreover, population 14 had the broadest leaf, while the shortest value of the leaf width was found in population 3 .

Significant correlations were registered between the ecological factors of habitat with some morphological traits. For example, the petiole length had a positive significant correlation ( $p \leq 0.01, r=0.47$ ) with northern distribution, while the same trait had a negative correlation ( $p \leq 0.01, r=-0.47)$ with soil $\mathrm{pH}$. These conditions hold true for the blade length. A positive significant correlation $(p \leq 0.01, r=0.39)$ was recorded between northern distribution with the blade length, but a negative significant correlation ( $p \leq 0.01, r=-0.47)$ was observed between the blade length with soil $\mathrm{pH}$. The pedicle length had a significant positive correlation $(p \leq 0.05, r=0.32)$ with eastern distribution of these populations. A significant negative correlation ( $p \leq 0.01, r=-0.40$ ) was found between the leaf blade width with soil $\mathrm{pH}$. Furthermore, some significant correlations were observed between morphological characteristics. For example, the petiole length had significant positive correlations $(p \leq 0.01)$ with the stem length, the blade length, and the width.

The studied populations were clustered separately in the UPGMA tree of morphological characteristics (Fig. 1); moreover, the PCA plot produced similar results. Therefore, the populations clustering in the tree are discussed. The UPGMA tree had two branches: the small branch consisted of population 3, but the remaining populations existed in the large branch that had two sub-branches. Population 1 was found in the small sub-branch, and other populations were observed in the large sub-branch, which was divided into two groups. Both groups had an equal number of populations. In a group we had two sub-groups; populations 9 and 10 


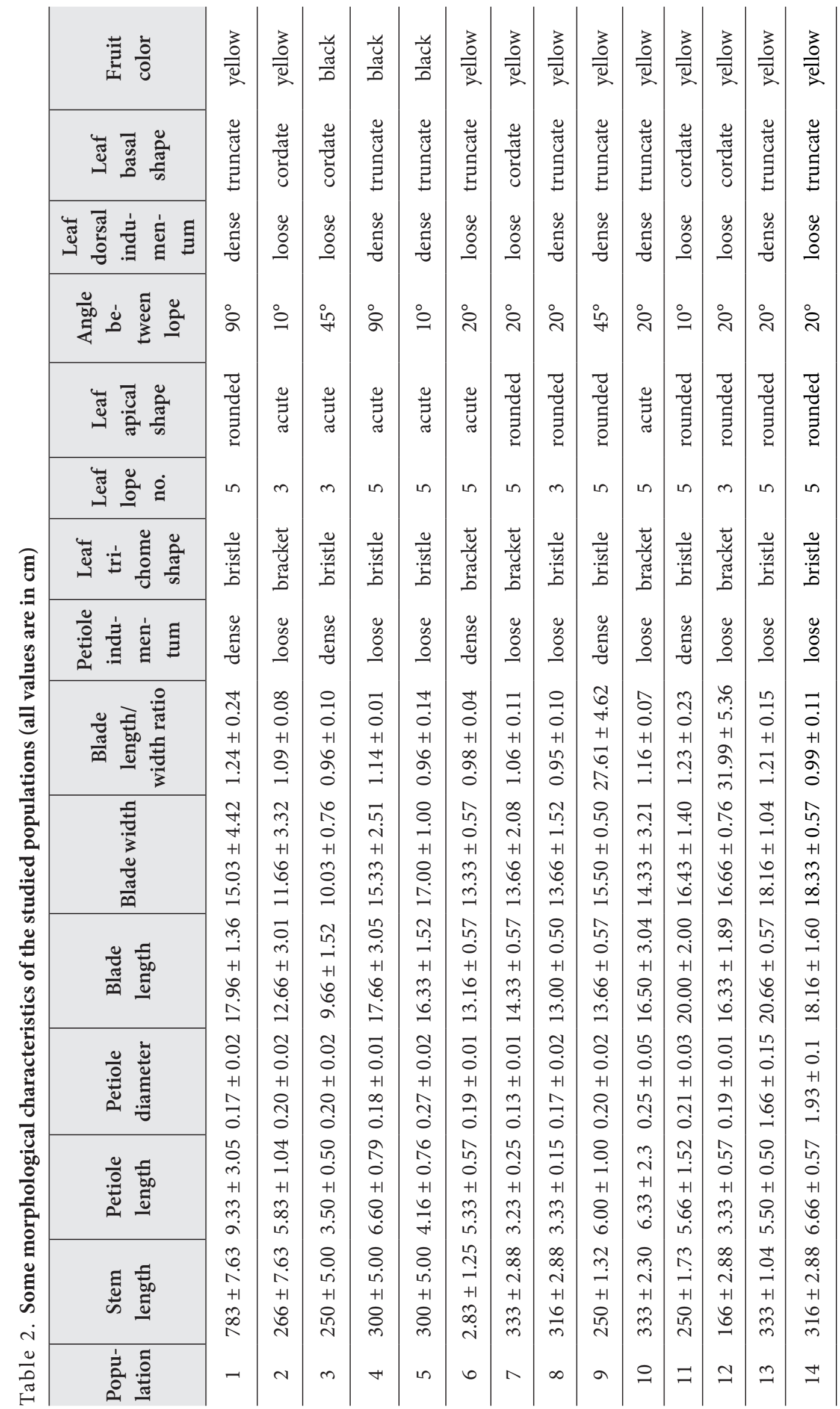


Table 3. Results of the ANOVA test among the quantitative morphological features of the studied populations

\begin{tabular}{|c|c|c|c|c|c|c|}
\hline & & Sum of squares & Degrees of freedom & Mean square & $\mathrm{F}$ & $P$-value \\
\hline \multirow{3}{*}{ Stem length } & Between groups & 775297.619 & 13 & 59638.278 & 5.566 & 0.000 \\
\hline & Within groups & 300000.000 & 28 & 10714.286 & & \\
\hline & Total & 1075297.619 & 41 & & & \\
\hline \multirow{3}{*}{ Petiole length } & Between groups & 115.037 & 13 & 8.849 & 5.661 & 0.000 \\
\hline & Within groups & 43.767 & 28 & 1.563 & & \\
\hline & Total & 158.804 & 41 & & & \\
\hline \multirow{3}{*}{ Petiole diameter } & Between groups & 13.334 & 13 & 1.026 & 324.401 & 0.000 \\
\hline & Within groups & 0.089 & 28 & 0.003 & & \\
\hline & Total & 13.423 & 41 & & & \\
\hline \multirow{3}{*}{ Blade length } & Between groups & 374.983 & 13 & 28.845 & 8.789 & 0.000 \\
\hline & Within groups & 91.893 & 28 & 3.282 & & \\
\hline & Total & 466.876 & 41 & & & \\
\hline \multirow{3}{*}{ Blade width } & Between groups & 218.521 & 13 & 16.809 & 3.912 & 0.001 \\
\hline & Within groups & 120.300 & 28 & 4.296 & & \\
\hline & Total & 338.821 & 41 & & & \\
\hline \multirow{3}{*}{$\begin{array}{c}\text { Blade length/ } \\
\text { width ratio }\end{array}$} & Between groups & 4271.141 & 13 & 328.549 & 0.916 & 0.549 \\
\hline & Within groups & 10042.809 & 28 & 358.672 & & \\
\hline & Total & 14313.949 & 41 & & & \\
\hline
\end{tabular}

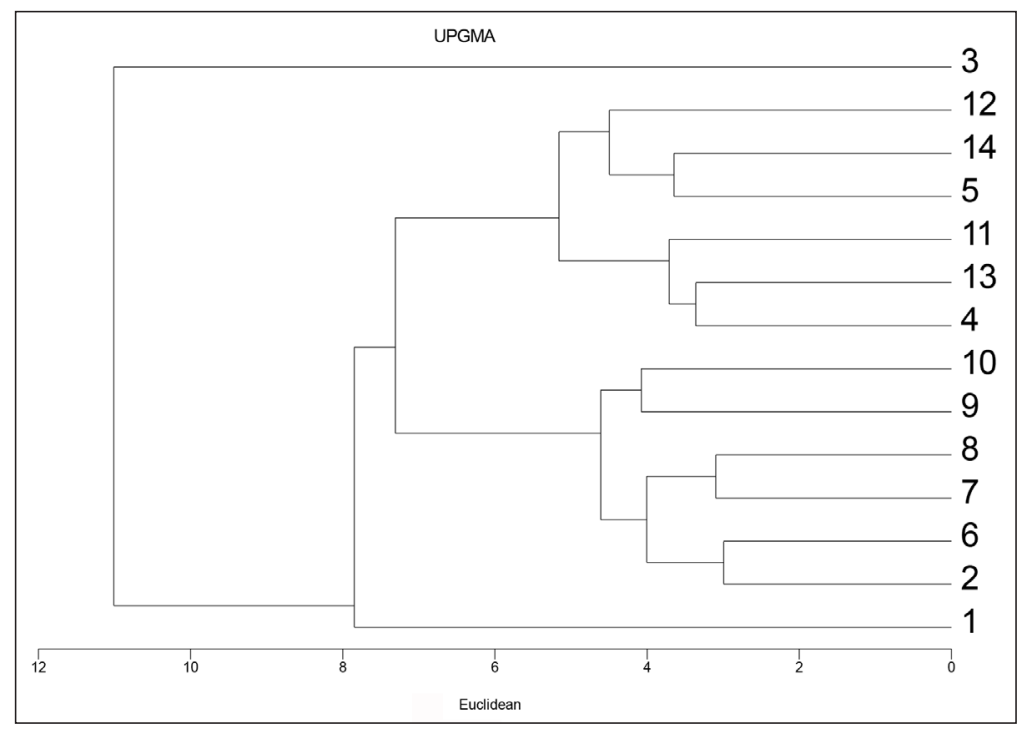

Fig. 1. The UPGMA tree of the studied populations by morphological variables (the numbering of the populations is the same as in Table 1) were found in a sub-group, while populations 6 and 2, as well as populations 7 and 8 , were placed as pairs. Another group consisted of two three-member sub-groups. In one, populations 4 and 13 were placed closely and population 11 was joined to them. A similar pattern was observed in other sub-group: populations 5 and 14 were clustered closely and population 12 was joined to them.

Thus, we found four distinct morphological groups among the studied populations. The CA-joined plot revealed that each pheno- type was characterized by special features that were very useful in their identification (Fig. 2). For example, population 1 was identified by the density of leaf ventral trichomes and the angle between leaf lopes. Based on some characteristics such as fruit colour, the number of leaf lopes, the petiole shape, the blade leaf length and width, population 3 was placed separately.

\section{SSR investigation}

Parameters of the genetic diversity of a population determined in 14 Iranian populations of 


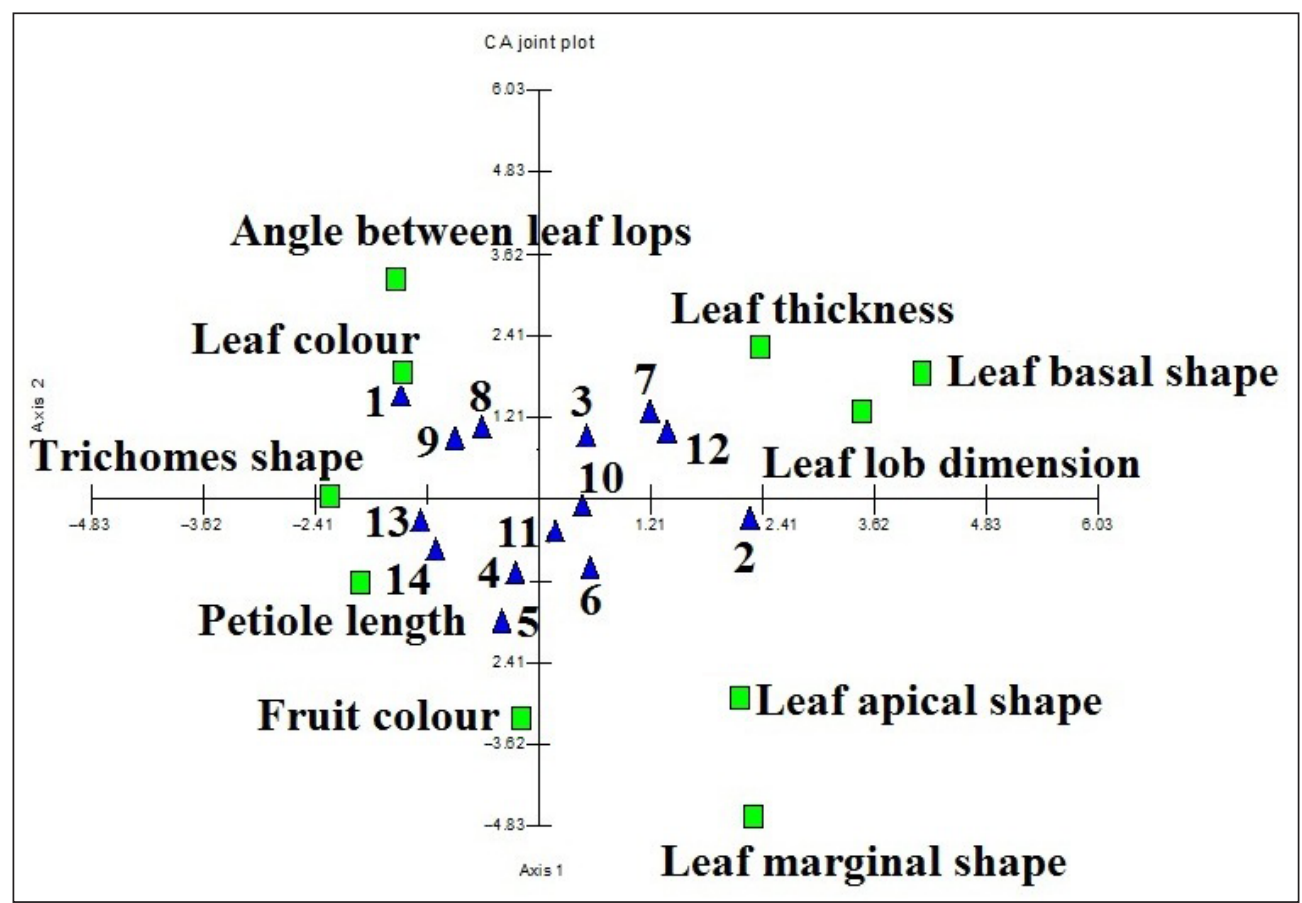

Fig. 2. CA-joined plot of the studied populations and morphological features (blue symbols are population numbers as in Table 1, green symbols are morphological traits)

the studied species are presented in Table 4. reported in populations 9 and 13, respectively. The highest (71.11\%) and the lowest (16.67\%) In addition, we found the highest values of gene amounts of the polymorphism percentage were diversity $(\mathrm{He})(0.203)$ in population 9 , while its

Table 4. Parameters of genetic diversity among the studied $F$. carica populations. Abbreviations: $\mathrm{Na}=$ No. of different alleles, $\mathrm{Ne}=$ No. of effective alleles $=1 /\left(\wedge p 2+q^{\wedge} 2\right), \mathrm{I}=$ Shannon's Information In$\operatorname{dex}=-1^{\star}\left(p^{\star} \operatorname{Ln}(p)+q^{\star} \operatorname{Ln}(\mathrm{q})\right), \mathrm{He}=$ expected heterozygosity $=2^{\star} p^{\star} q$, UHe $=$ unbiased expected het erozygosity $=(2 \mathrm{~N} /(2 \mathrm{~N}-1))^{\star} \mathrm{He}$, where for diploid binary data and assuming Hardy-Weinberg equilibrium, $q=(1-\text { Band Freq. })^{\wedge} 0.5$ and $p=1-q$

\begin{tabular}{cccccccccc}
\hline Population & $\mathrm{N}$ & $\mathrm{Na}$ & $\mathrm{Ne}$ & $\mathrm{I}$ & $\mathrm{He}$ & $\mathrm{UHe}$ & Polymorphism, \% \\
\hline Population 1 & 10.000 & 0.956 & 1.194 & 0.201 & 0.126 & 0.132 & 47.78 \\
\hline Population 2 & 16.000 & 1.133 & 1.243 & 0.250 & 0.159 & 0.164 & 56.67 \\
\hline Population 3 & 6.000 & 0.633 & 1.136 & 0.120 & 0.080 & 0.087 & 23.33 \\
\hline Population 4 & 8.000 & 0.644 & 1.119 & 0.121 & 0.077 & 0.083 & 25.56 \\
\hline Population 5 & 23.000 & 0.756 & 1.140 & 0.138 & 0.088 & 0.090 & 32.22 \\
\hline Population 6 & 10.000 & 0.789 & 1.206 & 0.184 & 0.122 & 0.128 & 35.56 \\
\hline Population 7 & 8.000 & 0.767 & 1.148 & 0.142 & 0.091 & 0.097 & 31.11 \\
\hline Population 8 & 5.000 & 0.511 & 1.123 & 0.109 & 0.073 & 0.081 & 20.00 \\
\hline Population 9 & 26.000 & 1.433 & 1.320 & 0.316 & 0.203 & 0.207 & 71.11 \\
\hline Population 10 & 10.000 & 1.011 & 1.312 & 0.265 & 0.179 & 0.188 & 48.89 \\
\hline Population 11 & 6.000 & 0.944 & 1.279 & 0.231 & 0.158 & 0.172 & 40.00 \\
\hline Population 12 & 5.000 & 0.589 & 1.135 & 0.117 & 0.079 & 0.088 & 21.11 \\
\hline Population 13 & 5.000 & 0.456 & 1.101 & 0.087 & 0.058 & 0.065 & 16.67 \\
\hline Population 14 & 5.000 & 0.533 & 1.118 & 0.101 & 0.068 & 0.075 & 18.89 \\
\hline
\end{tabular}


lowest amount (0.058) was observed in population 13. However, these conditions hold true for the Shannon information index (I), and its highest and lowest values were registered in populations 9 and 13, respectively.

We found significant molecular variations among the studied populations. According to the analysis of molecular variance (AMOVA) test (PhiPT $=0.47, P=0.01$ ), $75 \%$ of total genetic differentiation was due to the genetic difference within a population, and the rest $(25 \%)$ was due to the variations within the populations.

These populations are placed separately in the UPGMA tree of molecular SSR data (Fig. 3). This tree had two branches: the small branch contained population 9, while the remaining populations were grouped in the large branch, which was divided into two sub-branches. In the small sub-branch, populations 2 and 5 were found, and the other populations were clustered closely in the large sub-branch.

Moreover, MDS and PCoA plots produced similar results. In these plots, we observed four distinct groups: population 9 was placed far from the others, and these conditions hold true for populations 2 and 5, and each of which was recorded as an independent group. The remaining populations were clustered closely and registered as one group. The PCA-biplot revealed that each groups was characterized by some specific loci, which were created by the used SSR primers (Fig. 4).

We performed the Evanno test on Structure analysis and showed the best number of $k=4$ (Fig. 5). The genetic clustering pattern of the studied populations was similar to the results

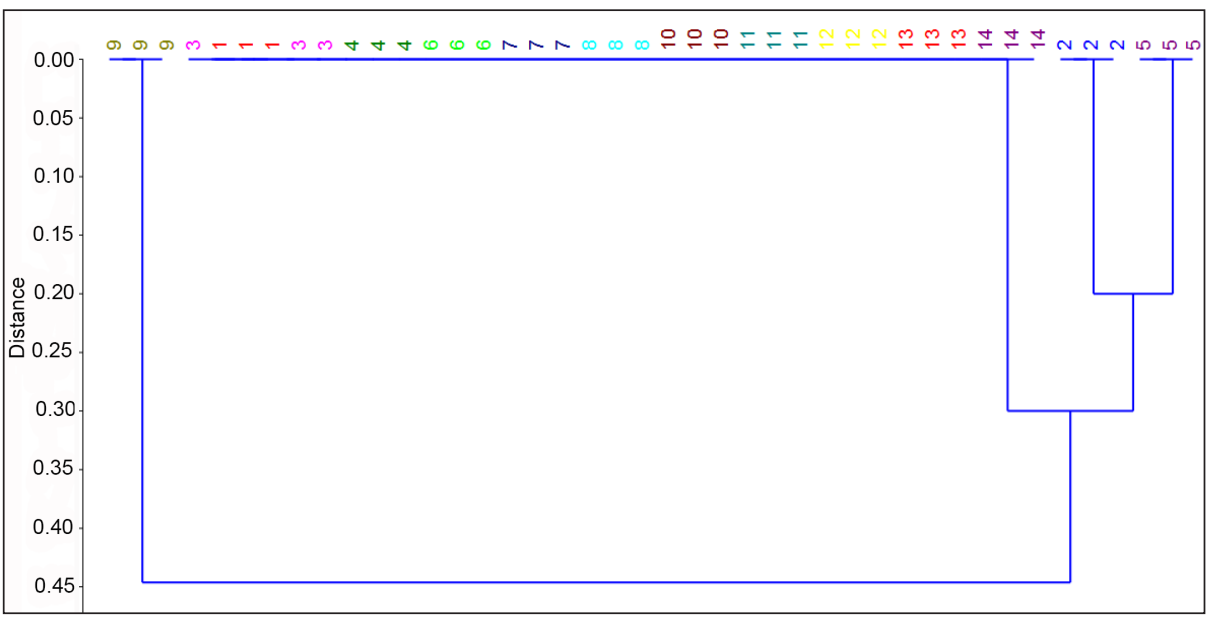

Fig. 3. The UPGMA tree of F. carica populations according to SSR results (the numbering of the populations is the same as in Table 1)

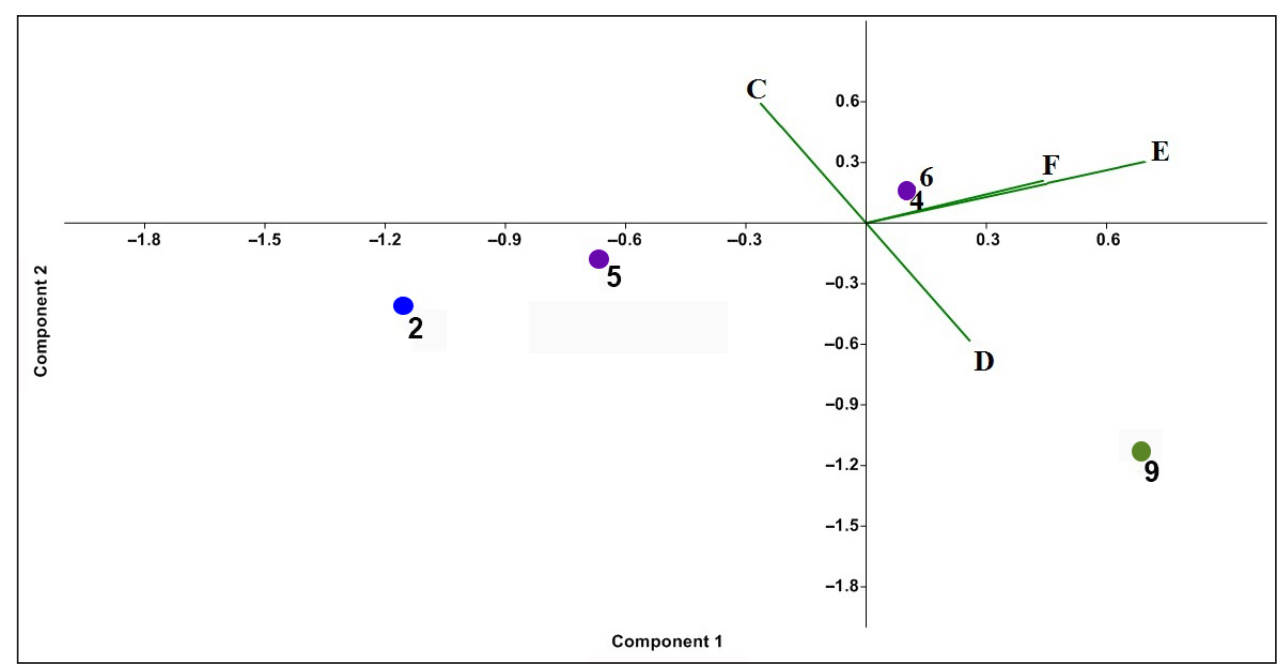

Fig. 4. PCAbiplot of the studied F. carica populations according to SSR loci

Abbreviations: the numbering of the populations is the same as in Table 1, the letters indicate loci created by used primers. 
of the UPGMA tree according to Nei's genetic distance. We registered four distinct genotypes.

The NeighborNet tree of the studied F. carica populations confirmed the existence of four distinct genotypes. Populations clustering in the NeighborNet tree were similar to those in the UPGMA tree according to Nei's genetic distance and also Structure analysis.

\section{DISCUSSION}

The SSR marker was widely used for the evaluation of genetic diversity among different species of Ficus. For example, Giraldo et al. (2005) investigated genetic variations among 13 species of the genus. Nazareno et al. (2009) used several microsatellite loci for cross amplification in samples of F. citrifolia and F. eximia.

The AMOVA test revealed significant variations among the studied populations, and most of them were found within populations rather than among populations. Therefore the genetic structure of most of the studied populations must be similar. Results of the UPGMA tree and PCoA and MDS plots confirmed the AMOVA test and eleven of studied populations closely clustered together. Moreover, NeighborNet and Structure analyses revealed high genetic similarity among most of the studied populations.

Our findings agreed with the results of previous genetic studies on F. carica. For example, Caliskan and Polat (2008) suggested that fig cultivars of various geographic origins exhibit high genetic similarity. Moreover, previous evaluations (Papadopoulou et al., 2002; SalhiHannachi et al., 2006) revealed that fig cultivars have a rather narrow genetic base.

$\mathrm{Nm}$, the calculated gene flow from Fst, was high and revealed a constant gene flow among the populations. Therefore, high genetic similarity was observed among the populations. Lowe et al. (2004) stated that constant and high amount of the gene flow among populations led to similarity of genetic structure and populations remain genetically stable over time. Furthermore, Nm decreased with an increasing $\mathrm{F}_{\mathrm{ST}}$ value, because greater differentiation among the populations of the same species cor- responds to lower levels of the gene flow (Freeland et al., 2011). Thus we had a large group of populations with a similar genetic structure among the studied populations. Geographical distances between some of these populations were more than $900 \mathrm{~km}$ and the gene flow is very low along this long distance. It seems that these populations had the same origin or were selected from the neighbouring populations that had high levels of the gene flow by pollinator. It is more important to know that a low genetic structure and a lack of isolation by distance point to a strong recent or historical gene flow (Hutchison, Templeton, 1999). Wagner et al. (1999) reported that Blastophaga psenses (L.) is the pollinator wasp for F. cari$c a$. The populations of this insect were widely found in different parts of Iran.

Adversely, some populations were clustered separately and had a unique genetic structure. It seems that these populations had a restricted gene flow with others. Wright (1943) found that the restriction of the gene flow may facilitate genetic differentiation between populations. Thus, populations should become genetically more isolated over distance. Isolation by distance is predicted to occur if the gene flow and the genetic drift are at equilibrium (Hutchison and Templeton, 1999).

Both vegetative and reproductive morphological characteristics varied among the studied populations. In addition, the ANOVA test revealed significant variations among most of the studied quantitative features.

Among vegetative organs, leaf features such as leaf dimensions, colour, basal and apical shapes and its indumentum of dorsal and ventral sides varied among these populations. Furthermore, significant variations existed between quantitative leaf traits with edaphic and geographical factors of a population's habitat. It showed that leaf traits varied in response to environmental conditions for better fitness of a plant within its habitat.

Our findings agree with previous infraspecific morphological studies on F. carica. They revealed that the number and the shape of leaf lobes (Saddoud et al., 2008), the leaf length, 
width and area, the trichome density of the upper surface of the leaf, petiole colour and dimensions, the depth of sinus (Podgornik et al., 2010; Gaaliche et al., 2012) were the main leaf characteristics for the discrimination of fig genotypes.

Moreover, fruit colour differed among populations and was useful for the identification of populations. Gaaliche et al. (2012) evaluated the morphological features of F. carica populations from Tunisia and found that morphological variables showed a large variability. Among the evaluated features, leaf dimensions, shoot dimensions, fruit shape and colour were very useful in identification of accessions.

According to morphological characteristics, four groups were found among these populations and each group was characterized by special morphological traits. The arrangement of populations did not agree with clustering of populations based on the molecular SSR data. Since significant correlations were found between some morphological features with environmental factors, we concluded that environmental factors have strong effects on phenotypical characteristics of the populations. These conditions were reported from various species of several families. For example, Talebi et al. (2014a) investigated morphological traits of different populations of Linum album (Linaceae) and reported high phenotypic variations among populations. Moreover, infraspecific morphological variations in response to ecological factors were found in several species of Lamiaceae such as Salvia limbata, Nepeta spp. (Talebi et al., 2018), Stachys inflata (Talebi et al., 2014b).

It seems that the pattern of morphological variations in the studied populations was not similar to those of genetic variations. Although in both studies we had four distinct phenotypes and genotypes among the studied populations, the members of these groups were not similar.

High morphological adaptations occurred among the studied populations, without sufficient genetic support, therefore a high level of phenotypic plasticity exists in the studied populations. Apparently, the morphotypes found among these populations are ecophene. Also, the reported genotypes of these populations are not recognizable based on the morphological characteristics.

\section{CONCLUSIONS}

High morphological variations were reported in morphological characteristics of F. carica populations. According to the UPGMA tree and the PCA plot of morphological traits, four distinct phenotypes were observed that were identified by special morphological features. The AMOVA test revealed significant molecular variations within and among the studied populations. We found four similar genotypes in the UPGMA tree, the MDS plot, and Structure analyses of SSR data. Morphological clustering of populations was not similar to the molecular one. This concludes that phenotype plasticity occurred in response to better fitness of populations within their habitats and the genotypes were not recognized by their morphological characteristics.

Received 16 March 2019

Accepted 21 August 2019

\section{References}

1. Azizian D. Flora of Iran no. 35, Moraceae. Islamic Republic of Iran, Tehran: Ministry of Jahad-e-Sazandegi; 2001. p. 9-27.

2. Caliskan O, Polat A. Fruit characteristics of fig cultivars and genotypes grown in Turkey. Scientia Hort. 2008; 115(4): 360-7.

3. Chawla A, Kaur R, Kumar Sharma A. Ficus carica Linn.: a review on its pharmacognostic, phytochemical and pharmacological aspects. Int J Pharm Phytopharmacol Res. 2012; 1(4): 215-32.

4. Condit LJ. Fig varieties: a monograph. Hilgardia. 1955; 23: 323-538.

5. Darlington CD, Wylie AP. Chromosome atlas of flowering plants. 2nd ed. London: George Allen \& Unwin Ltd.; 1945. p. 183-5. 
6. Evanno G, Regnaut S, Goudet J. Detecting the number of clusters of individuals using the software STRUCTURE: a simulation study. Mol Ecol. 2005; 14(8): 2611-20.

7. Jeong M, Kim HY, Cha JD. Antimicrobial activity of methanol extract from Ficus carica leaves against oral bacteria. J Bacteriol Virol. 2009; 39(2): 97-102.

8. Falush D, Stephens M, Pritchard JK. Inference of population structure using multilocus genotype data: dominant markers and null alleles. Mol Ecol Notes. 2007; 7(4): 574-8.

9. Freeland JR, Petersen SD, Kirk H. Molecular Ecology. 2nd edition. Chichester: WileyBlackwell; 2011. 464 p.

10. Gaaliche B, Saddoud O, Mars M. Morphological and pomological diversity of fig (Ficus carica L.) cultivars in Northwest of Tunisia. ISRN Agronomy. 2012; Article ID 326461: 2012. 9.

11. Giraldo E, Viruel MA, Lopes-Corrales M, Hormaza JI. Characterization and crossspecies transferability of microsatellites in the common fig (Ficus carica L.). J Hortic Sci Biotech. 2005; 80: 217-24.

12. Hedrick PW. A standardized genetic differentiation measure. Evolution. 2005; 59(8): 1633-8.

13. Huson DH, Bryant D. Application of phylogenetic networks in evolutionary studies. Mol Biol Evol. 2006; 23(2): 254-67.

14. Hutchison DW, Templeton AR. Correlation of pairwise genetic and geographic distance measures: Inferring the relative influences of gene flow and drift on the distribution of genetic variability. Evolution. 1999; 53(6): 1898914.

15. Khadari B, Hochu I, Santoni S, Kjellberg F. Identification and characterization of microsatellite loci in the common fig (Ficus carica L.) and representative species of the genus Ficus. Mol Ecol Notes. 2001; 1: 191-3.

16. Lowe A, Harris S, Ashton P. Ecological genetics: design, analysis and application. Malden, USA, Oxford: Blackwell; 2004. 344 p.
17. Meirmans PG. AMOVA-based clustering of population genetic data. J Hered. 2012; 103(5): 744-50.

18. Meirmans PG, Van Tienderen PH. GENOTYPE and GENODIVE: two programs for the analysis of genetic diversity of asexual organisms. Mol Ecol Notes. 2004; 4(4): 792-4.

19. Nazareno AG, Pereira RAS, Feres JM, Mestriner MA, Alzate-Marin AL. Transferability and characterization of microsatellite markers in two Neotropical Ficus species. Genet Mol Biol. 2009; 32(3): 568-71.

20. Papadopoulou K, Ehaliotis C, Tournal M, Kastanis P, Karydis I, Zervakis G. Genetic relatedness among dioecious Ficus carica L. cultivars by random amplified polymorphic DNA analysis, and evaluation of agronomic and morphological characters. Genetica. 2002; 114(2): 183-94.

21. Patil Vikas V, Bhangale SC, Patil VR. Evaluation of anti-pyretic potential of Ficus carica leaves. Int J Pharm Sci Rev Res. 2010; 2(2): 48-50.

22. Peakall R, Smouse PE. GENALEX 6: genetic analysis in Excel. Population genetic software for teaching and research. Mol Ecol Notes. 2006; 6: 288-95.

23. Podani J. Introduction to the exploration of multivariate biological data. Leiden: Backhuys; 2000.407 p.

24. Podgornik M, Vuk I, Vrhovnik I, Mavsar DB. A survey and morphological evaluation of fig (Ficus carica L.) genetic resources from Slovenia. Sci Hort. 2010; 125(3): 380-9.

25. Pritchard JK, Stephens M, Donnelly P. Inference of population structure using multilocus genotype data. Genetics. 2000; 155(2): 945-59.

26. Rahnavard A. Genetic and biochemical diversity of Hypericum Perforatum L. grown in the Caspian climate of Iran. Appl Ecol Env Res. 2017; 15(1): 665-75.

27. Saddoud O, Baraket G, Chatti K, Trifi M, Marrakchi M, Salhi-Hannachi A, Mars M. Morphological variability of fig (Ficus carica L.) cultivars. Int J Fruit Sci. 2008; 8: 35-51. 
28. Salhi-Hannachi A, Chatti K, Saddoud O, Mars M, Rhouma A, Marrakchi M, Trifi M. Genetic diversity of different Tunisian fig ( $F i$ cus carica L.) collections revealed by RAPD fingerprints. Hereditas. 2006; 143: 15-22.

29. Storey WB. Figs. In: Janick J, Moore JN, editors. Advances in fruit breeding. Purdue University Press, West Lafayette, Indiana. 1975; 568-89.

30. Talebi SM, Atri M, Sheidai M, Sharifnia F, Noormohammadi Z. Infraspecific variations in Linum album based on the determination of special stations approach in Iran. Phytologia Balcanica. 2014a; 20(1): 9-22.

31. Talebi SM, Salahi-Esfahani G, Azizi N. Inter and intrapopulation variations in Stachys inflata Benth., based on phenotype plasticity (an ecological and phytogeographical review). Int Res J Biol Sci. 2014b; 3(2): 9-20.

32. Talebi SM, Nohooji MG, Yarmohammadi M, Azizi N, Matsyura A. Trichomes morphology and density analysis in some Nepeta species of Iran. Mediterranean Botany. 2018; 39(1): 51-62.

33. Yan W, Zhao M, Ma Y, Pan Y, Yuan W. Primary purification of two antifungal proteins from leaves of the fig (Ficus carica L.). Afr J Biotechnol. 2011; 10(3): 375-9.

34. Wagner WL, Herbst DR, Sohmer SH. Manual of the flowering flants of Hawai'i. 2 vol. Bishop Museum Special Publication 83, University of Hawai'i and Bishop Museum Press, Honolulu, HI. 1999; 1919 p.

35. Wright S. Isolation by distance. Genetics. 1943; 28(2): 114-38.
Mohammad Reza Zolfaghari, Fahimeh Salimpour, Fariba Sharifnia, Maryam Peyvandi, Sayeh Jafari Marandi

\section{INFRASPECIFINĖS MORFOLOGINĖS IR GE- NETINĖS SKIAUTE்TALAPIO FIKUSO FICUS CARICA L. VARIACIJOS IRANE}

\section{Santrauka}

Skiautetalapis fikusas (Ficus carica L. (Moraceae) yra vienas svarbiausių pasèlio augalų visame pasaulyje. Irane auga net keliolika laukinių ir kultūrinių šio augalo populiacijų. Šiame tyrime pasitelkus morfologinius ir molekulinius SSR metodus siekta nustatyti infraspecifines rūšies variacijas bei sukurti ir ittraukti naujus galimus fenotipus / genotipus it auginamas populiacijas. Tyrimui atrinkta 14 šio augalo populiacijų iš skirtingų šalies regionų ir ivvertinti 27 reprodukcinių ir vegetatyvinių organų kokybiniai ir kiekybiniai morfologiniai požymiai. ANOVA testas atskleidè reikšmingas variacijas, nulemiančias kiekybinius augalo požymius, taip pat pastebėti kokybinių požymių skirtumai tarp populiacijų. Reikšmingos koreliacijos nustatytos tarp kelių morfologinių požymių ir ekologinių buveinių. Pagal sudarytą UPGMA medị, tarp šių populiacijų egzistavo 4 morfotipai. „CA-Joined“ grafike populiacijos buvo identifikuojamos pagal morfologinius kintamuosius. AMOVA testu nustatytos reikšmingos variacijos, kurių dauguma priklausè skirtingų populiacijų variacijoms. Remiantis UPGMA medžiu, MDS ir PcoA grafikais, studijuotos populiacijos buvo suskirstytos į 4 genotipus. STRUCTURE analizė patvirtino šias grupes. Trys grupès buvo monotipinès, o ketvirtąją sudarè vienuolika populiacijų. Populiacijų klasterizacijos modeliai pagal morfologinius požymius nebuvo panašūs ị SSR duomenų modelius. Daroma išvada, kad ekologiniai veiksniai turèjo dideli poveiki populiacijų fenotipams ir genotipams, kurie nebuvo atpažistami pagal jų fenotipus.

Raktažodžiai: F. carica, SSR, morfologija, populiacijos, genetinès variacijos 